\title{
THE ANALYSIS OF ATTITUDE STRUCTURE DIFFERENCES (COGNITIVE, AFECTIVE, CONATIVE) INTAKO' CONSUMERS, TANGGULANGIN SIDOARJO
}

\author{
Bambang Setyadarma ${ }^{1}$ \\ Tri Tjahjo Poernomo ${ }^{2}$ \\ Economics and Business Faculty \\ Wijaya Kusuma University \\ bsbambang1@gmail.com
}

\section{A R T I C L E I N F O}

Article history:

Received : 31 Oct 2020

Revised : 15 Nov 2020

Accepted : 25 Nov 2020

Key words:

Affective, cognitive, conative, cluster sampling

\begin{abstract}
A B S T R A C T
The research objective in this research article aim to understand and examine more deeply the relevance of these consumer attitudes as a basic concept to satisfy the various needs of a consumer in an integrated and organized manner in the field. The research sampling used a cluster sampling approach (Cooper \& Emory, 1995), divided into 3 clusters: cognitive cluster (25 participants), affective cluster (25 participants), conative cluster (25 participants) as regular consumers of INTAKO products Tanggulangin, Sidoarjo. The research hypothesis can be accepted factually. Based on the grouping of the three components of attitude above, the writer can conclude that it is the cognitive component that plays a greater role in consumers when they want to make a purchase decision for a product or service. This reality has closed relevance to social phenomena that are generally accepted in various circles of society.
\end{abstract}

\section{INTRODUCTION}

As consumers, we can have various attitudes towards the manufacturing process, advertising services, direct orders via e-mail, Cybernet, or retail stores. Regarding the basic concept of consumer behavior, the perception of various common attitudes can contribute positively to developing an essential strategy for understanding a consumer's conditionality. To get to the primary realm of each consumer's impulsive behavior, the actualization of basic applied research can be used to examine various problems in strategic marketing activities.

The research objectives in this research article aim to understand and examine the relevance of these consumer attitudes as a fundamental concept to satisfy the various needs of a consumer in an integrated and organized manner in the field. The philosophy itself is a description of a tendency that must be examined for its correctness to behave in a pleasing or unsatisfactory pattern of an object (such as the classification of a product, service, advertising, Cybernet, or retail market).

Each indicator in this articulation is handy in understanding what and how an attitude tends to be related to consumer behavior and existing marketing activities. The essential words related to an introduction to attitudes towards consumers themselves must be perceived globally. A concept that is closely related to consumption patterns and the specifics of marketing activities, such as products, product classification, services, licenses, product consumption, advertisements, Cybernet, prices, suppliers. or retailers.

An illustrative example is interested in studying and understanding consumer attitudes towards two bicycle product brands. "Through empirical evidence on the 
study of two bicycle products, namely: Gaselle and Polygon. Philosophy itself is a tendency that is learned and interpreted. Attitudes are closely related to purchasing behavior, which is formed as actualization through a direct experience related to products, verbal information obtained through other people, or exposure to advertisements on social media, Cybernet, or completion of direct marketing activities (such as retail catalogs). The attitude itself has the quality to stimulate the consumer to motivate consumers to a particular mood or to attract consumer interest from a confident perspective.

Attitudes have the consistency of the diversity of characteristics through the philosophy itself, which explains that attitudes have consistent relevance to the actualization of the behavior it reflects. Although it has consistency, attitudes do not always have a character, which means attitudes can change at any time. As an example, a customer prefers to choose Samsung products over Nokia products. Actual attitudes in certain conditions, where conditions summarize several conditions that occur at certain moments, can affect the relationship between philosophy and behavior.

A specific condition can cause each consumer to behave in a way that is not consistent with their attitude. For example, a homemaker frequently shops for Nike branded shoes, but under certain conditions, her constitution can only afford to buy shoes with the Diadora brand. When we measure attitudes, it is essential to consider the behavior's needs if it cannot be wrong to correct the relationship between attitudes to action. The most important thing in understanding the role of an attitude in consumer behavior is the definition of the structure and composition of attitudes.

There are four basic attitude models: The 3 component attitude model consists of 3 main components: a. The cognitive part is the first component of the three attitude component models comprised of various cognitions through knowledge and perceptions obtained based on direct experience. Attitude objects with multiple properties and certain behaviors can cause specific outputs.

For example, a consumer wants to buy a Daihatzu Xenia with a Datsun go. Daihatzu is better than Datsun in terms of machining technology, where there are more Daihatzu car variants than Datsun. And the price of Daihatzu spare parts is easier to get in the general market. Because the Astra National Corporation has merged Daihatzu's fabrication management, Astra has opened Daihatzu dealers, especially for the general sales division and service services in several parts of the country. A reliable mechanic in the automotive sector and has national trading experience at Astra Nasional, Jakarta, with the support of the Astra Sedayu Finance Group's financial leasing services, a subsidiary of the Astra Group Jakarta.

Suppose consumers want to buy a car by leasing through a term installment process. In that case, they can make a credit agreement through the car finance institution, namely the Astra Sedayu Finance Group. Simultaneously, for fabrication management, Datsun has not established branch dealers, currently specifically for the general sales division, and service services are not yet available In some parts of the country today because Datsun management stands independently. The price of its auto parts is higher than that of adult Daihatzu and dealers in the sales and service division are still limited in several major cities in Indonesia. Its existence is not comprehensive, unlike Astra International. Groups spread from Sabang to Merauke are supported by international work patterns.

This is what makes consumers prefer Daihatzu cars to the Datsun brand. $b$. The affective component describes consumers' emotions or feelings regarding a particular product or brand and is affective of a confident attitude. Researchers often consider these emotions and feelings that 
consumers are very evaluative because they include one's assessment of the object of philosophy as a whole and factually.

Some research suggests that this emotional state can reinforce positive or negative experiences. The memory of these experiences can influence the mind and mind and how the individual responds to action. For example, when a homemaker experiences boredom, she usually spends her time at a beauty salon or a mall to do shopping activities. c. The conative component is the last component of the three members of attitude related to the various possibilities or tendencies that individuals will take specific actions or behave in certain particular attitude objects. According to some understanding, the conative component may include the scope of the real behavior itself. In some marketing and consumer research, this component is often seen as a manifestation of the consumer's purchasing activity goal. The purchase objective pattern is used to assess several possible factors for consumers to purchase a product or behave in specific ways. The multi-trait attitude model describes consumer attitudes towards attitude objects such as products, services, leaflets, detailed information. As the use of consumer perceptions and self-assessments of the main characteristics or beliefs that are believed to be related to the object of this particular attitude.

This research article\&\#39;s main problem explains that conceptually marketing has three models in multi-trait attitudes: 1.Attitude toward objects, 2.Attitudes toward behavior, 3. Reasonable action model theories. Based on the third approach to the multi-trait attitude model, which has harmony with the current research object, namely: Model 1 (Model Attitudes Towards Objects).

The object of research in this article tends to consumers; purchasing decisions of INTAKO products in the Tanggulangin area, Sidoarjo. The researcher seeks to conduct a more in-depth study of the differences between the three attitude structures (cognitive, affective, and conative). From the three attitude structures, it has the closest relevance to consumer purchasing decisions of INTAKO products.

\section{THEORICAL BASIS}

Attitude component

According to (Damiati et al. 2017), conceptually, the attitude has three main components, including 1 . The cognitive feature is the first component of a person's mental attitude, namely knowledge and perception obtained through direct experience with the object of philosophy and information about that object. Itself obtained through various sources.

Knowledge and the resulting perceptions usually form beliefs, meaning that consumer beliefs explain that particular attitude objects have specific attributes and behaviors that cause individual results. 2 . The affective component is a component that is directly related to the emotional factor and feelings towards an object.

This feeling reflects an overall evaluation of consumers towards a particular object, which is how much consumers feel like or dislike.

The conative component is a component related to the possibility or tendency that someone will take specific actions associated with the attitude's object. The conative part is often used as an expression through the consumer's intention to make a purchase.

(Azwar, 2012) argues that the attitude structure consists of 3 interrelated components, namely: 1 . Cognitive components contain a person's stereotypical beliefs regarding what applies or what is true of the object of attitude. Sometimes, this component's structure can be perceived as having the same views or opinions, especially when it comes to issues or controversial problems. 2. The affective component is an expression of personal feelings towards the object of attitudes and concerns emotional issues. This emotionality problem usually leads to the 
dimensionality of changes that will change a person's perspective. 3 . The conative component is the formation of an attitude pattern that shows how the behavior or tendency to behave in a person is related to the object of the attitude he faces. Through action and self-study, a person will gain trust and perspectives, ultimately affecting his behavior.

Based on the three components of attitude above, the writer can conclude that the cognitive part plays a more significant role in consumers when deciding on a product or service. Because these views/opinions have immediate relevance to a moment/events that occur in society, where the incident has taken place is supported and strengthened by the statement of someone who has experienced it first and can be retold through other people and believe in things. This is a factual matter, especially closely related to a consumer's purchase decision (as a good thing that can be recommended to other parties to a purchase decision for goods or services).
(Ramadhan \& Pangestuti, 2018) have conducted research activities with the topic "the influence of consumer attitudes on purchasing decisions for ecolabel products (studies on PT Ultra Jaya products)," This research activity was carried out to know the indicators of consumer attitude parameters which have the relevance of dominant influence on parameters of ecolabel product purchasing decisions on products of PT. Ultra Jaya.

The research sampling was carried out purposively with the main target: a group of people who consume the Ultra Jaya business corporation ecolabel product (FIA Unibraw students class of 2012/2016). The final implication of this research is that the parameters of consumer attitudes (brand evaluation) have a dominant influence on purchasing decisions for Ultra Jaya ecolabel products.

\section{Hypothesis}

H1: Cognitive, Affective, Conative Attitude of INTAKO consumers (bag and luggage industry) Tanggulangin, Sidoarjo is significantly different.

\section{Analysis Model}

\section{RESEARCH METHOD}

Population and Sample

The study population consists of all consumers who shop for INTAKO products in the Tanggulangin area, Sidoarjo. The research sampling used a cluster sampling approach (Cooper \& Emory, 1995), divided into 3 clusters: 1 . Cognitive collection (25 participants), 2. Affective group (25 participants), 3. Conative group (25

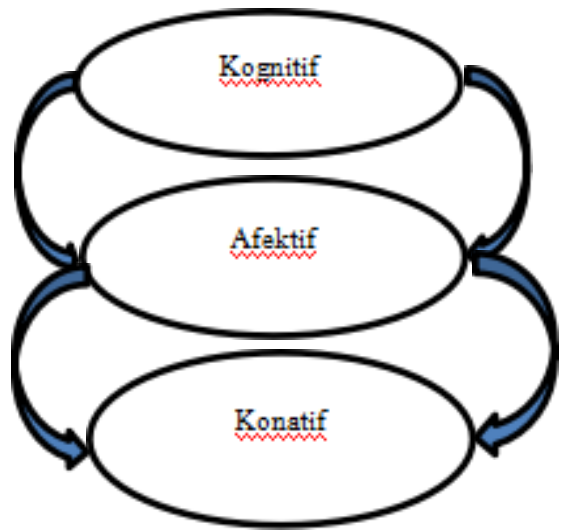

participants) as regular consumers of INTAKO products Tanggulangin, Sidoarjo. With Criteria:

1. Minimum age of 17 years (gender-free)

2. Understand the benefits and use-value of INTAKO products

Variable

The research variables were grouped into three components: 1 . Cognitive 
Attitude, 2. Affective Attitude, 3. Conative Attitude

\section{$\underline{\text { Paradigm }}$}

This research article is quantitative by examining the differences in the 3 Attitude Structures (Cognitive, Affective, Conative) where the differences between the 3 Consumer Attitude Structures can be studied in more depth through the statistical inferential approach (Multivariate Analysis of Variance (MANOVA), to support factual empiricism. Research hypothesis (Cooper \& Emory, 1995).

\section{$\underline{\text { Research Model }}$}

Using the Multivariate Analysis of Variance (MANOVA) approach

\section{RESULT}

Table 1 Levene's Test of Equality of Error Variancesa

\begin{tabular}{|l|l|l|l|l|}
\hline & F & df1 & df2 & Sig. \\
\hline Kognitif & 22.597 & 5 & 19 & .000 \\
Afektif & 6.294 & 5 & 19 & .001 \\
Konatif & 8.388 & 5 & 19 & .000 \\
\hline
\end{tabular}

a. Design: Intercept + kelompok_kosumen

Based on Levene's test analysis, it is clear that the three consumer clusters (cognitive, affective, conative) are significantly different. The mental collection has the support of the Levene's test significance coefficient of $(.000<$ from prob std. .050), the affective cluster of (.001 <from. prob std .050), the conative collection is (.000 < of prob std .050).

Cognitive cluster consumers perceive that intako products are products that have high benefits and use value, this is based on the perceptions of consumers that these intako products inform that the product quality of intako shoes is not inferior to products made in Cibaduyut, where consumers who have used shoes with acrylic products can survive. For three years, and is comfortable when used for office activities. It does not cause blisters on the feet. And the price variants offered by the intako merchant association are not too expensive compared to other products outside of the concrete. This makes the customers of intako products commit to continue to use the cement products sustainably according to their current purchasing power and needs.

The consumer perceptions of the affective cluster explain that the existence of intako products today prefers products. Especially among teenagers who tend to like colorful women's bags with various patterns and today's millennium models with prices that are quite affordable for visitors who take the time to shop for bags. Picnic or bag for office use. They have a very positive perception of the bag model's variant offered by the association of bag merchants, intako products that are not inferior to those made by small industries in Wedoro, Waru Sidoarjo. However, the distance to Wedoro is closer than Tanggulangin, Sidoarjo.

Due to the immense diversity of women's bag variants offered by the managers of the small industry that are incorporated in the intake, young people who come from young women (female students or students) are interested in seeing the latest trends in the millennium bag model displayed by these intake merchants for attracting enthusiastic 
visitors who are passionate about coming to the location of sales of intako products in Sidoarjo especially on Sundays or national holidays to take a walk or buy these intako products, because consumers need the latest bag models that are not inferior to the appearance of available bag variants. Offered at the Matahari Tunjungan Plaza gallery today with a cheaper price difference adjusting the people's purchasing power from the middle to lower economic class.

This is the main attraction for young women who come from Surabaya to shop for bags or shoes made by Tanggulangin intako, Sidoarjo for now.

The conative cluster's consumer perception explains that intako products' quality can be trusted even though they only come from small industrial artisans and are supported by minimal business capital. With the SME guidance carried out by the Sidoarjo regional small industry development office as well as the support of micro credit funds offered by the BNI financial institutions and the East Java $\mathrm{BPR}$, the competitiveness of these Intako products is not inferior to shoes, leather bags, and luggage products from the country of China.

The sustainability of the small industry's potential in Tanggulangin can provide positive motivation for the craftsmen into products to increase the quality and variety of the latest product variants. The success of developing the aesthetic value of bags, shoes, and luggage products made from quality cowhide and vinyl cannot be separated from the support of semi-modern production process technology to increase the competitiveness of Intako Tanggulangin's products in the Javanese national market segment. East.

The diversity of product variants of bags, luggage, shoes, and sandals is utterly available in each of the Tanggulangin intako merchant association's counter displays.

The consumers of Tanggulangin intako remain motivated to believe that the credibility of the intako Tanggulangin product can be accounted for and is a national quality superior product produced by small industry craftsmen, especially Intako Tanggulangin Sidoarjo today.

The research hypothesis can be accepted factually. Based on literature review and empirical analysis of retail marketing, it is concluded that consumer perceptions and self-assessments of the main traits or beliefs that are believed to be related to this particular attitude object.

Tabel 2 (F-Model test)

\begin{tabular}{|c|c|c|c|c|}
\hline Effect & & $\mathrm{F}$ & $\begin{array}{l}\text { Hypothesis } \\
\mathrm{df}\end{array}$ & Sig. \\
\hline \multirow[t]{4}{*}{ Intercept } & Pillai's Trace & $908.433^{b}$ & 2.000 & .000 \\
\hline & Wilks' Lambda & $908.433^{\mathrm{b}}$ & 2.000 & .000 \\
\hline & $\begin{array}{l}\text { Hotelling's } \\
\text { Trace }\end{array}$ & $908.433^{b}$ & 2.000 & .000 \\
\hline & $\begin{array}{l}\text { Roy's Largest } \\
\text { Root }\end{array}$ & $908.433^{b}$ & 2.000 & .000 \\
\hline \multicolumn{2}{|c|}{ kelompok_kosu Pillai's Trace } & 3.726 & 10.000 & .002 \\
\hline \multirow[t]{3}{*}{ men } & Wilks' Lambda & $4.671^{\mathrm{b}}$ & 10.000 & .000 \\
\hline & $\begin{array}{l}\text { Hotelling's } \\
\text { Trace }\end{array}$ & 5.663 & 10.000 & .000 \\
\hline & $\begin{array}{l}\text { Roy's Largest } \\
\text { Root }\end{array}$ & $11.464^{c}$ & 5.000 & .000 \\
\hline
\end{tabular}


Based on the analysis (F-model test), it is concluded that Roy's Largest Root has the feasibility of dominating the consumer $\mathrm{F}$ Model $(11,464)$ compared to other consumer models, Pillai's Trace $(3,726)$, Wilks' Lambda $(4,671)$, Hotelling's Trace $(5,663)$.

\section{CONCLUSIONS}

The research hypothesis can be accepted factually. Based on the three components of attitude above, the writer can conclude that the cognitive part plays a more significant role in consumers when deciding on a product or service.

This reality has immediate relevance to social phenomena that are generally accepted in various circles of society. And it has been proven by a consumer who has consumed a product and can re-recommend his experience to other parties regarding a purchase decision.

\section{LIMITATIONS}

This research is only concentrated on the object of observation of the structure of attitudes, divided into three components. It is advisable for other research activities to develop the statement's object, namely suggesting applied observational studies related to the importance of customer preference actions in supporting hedonic purchasing decisions in global marketing (case study East Java area marketing).

\section{REFERENCE}

Azwar, S. (2013). Teori Sikap Manusia (edisi ke 2), Yoyakarta: Pustaka Belajar

Cooper, D.R \& CW Emory, (1995). Business Research Methods, 5th Ed Richard D. Irwin, Inc. New York.

Damiati. et al. (2017). Struktur Sikap. ISBN: 078-602-425-199-4 Halaman: 236

Ramadhan, M Afif \& Pangestuti Edriana, (2018). Pengaruh Sikap Konsumen Terhadap Keputusan Pembelian Produk Ekolabel (Studi Pada Produk PT. Ultra Jaya). Jurnal Administrasi Bisnis (JAB) Vol. 57 No 1. Fakultas Ilmu Administrasi Uniniversitas Brawijaya Malang. 


\section{APPENDIX}

Levene's Test of Equality of Error Variances ${ }^{a}$

\begin{tabular}{|l|l|l|l|l|}
\hline & & & & \\
\hline Kognitif & 22.597 & 5 & 19 & .000 \\
& 6.294 & 5 & 19 & .001 \\
Afektif & 8.388 & 5 & 19 & .000 \\
Konatif &
\end{tabular}

a. Design: Intercept + kelompok_kosumen

\section{F Model Test}

\begin{tabular}{|c|c|c|c|c|}
\hline \multicolumn{2}{|l|}{ Effect } & \multirow{2}{*}{$\frac{F}{908.433^{b}}$} & \multirow{2}{*}{$\begin{array}{r}\text { Hypothesis df } \\
2.000\end{array}$} & \multirow{2}{*}{$\frac{\text { Sig. }}{.000}$} \\
\hline & Pillai's Trace & & & \\
\hline & Wilks' Lambda & $908.433^{b}$ & 2.000 & .000 \\
\hline & Hotelling's Trace & $908.433^{b}$ & 2.000 & .000 \\
\hline & Roy's Largest Root & $908.433^{b}$ & 2.000 & .000 \\
\hline kelompok_kosumen & Pillai's Trace & 3.726 & 10.000 & .002 \\
\hline & Wilks' Lambda & $4.671^{b}$ & 10.000 & .000 \\
\hline & Hotelling's Trace & 5.663 & 10.000 & .000 \\
\hline & Roy's Largest Root & $11.464^{\mathrm{c}}$ & 5.000 & .000 \\
\hline
\end{tabular}

